\title{
Diskurz tance / diskurz o tanci: Současné tendence německé taneční vědy
}

\author{
Dance Discourse / Discourse on Dance: \\ Current Tendencies in German Dance Studies \\ Jitka Pavlišová / Barbora Liška
}

\begin{abstract}
Abstrakt
Cílem studie je představit a kontextualizovat genezi oboru taneční věda v německojazyčném (Tanzwissenschaft) a angloamerickém prostředí (Dance Studies) a přiblížit stěžejní argumentační principy při jeho formování coby samostatného univerzitního oboru. Detailnější pozornost je zaměřena na specifika německé taneční vědy a na její základní vědecké př́stupy a modifikace, které v tamním současném diskurzu obzvláště rezonují. Studie následně blíže nazírá několik konkrétních teoretických konceptů, které autorky považují za zásadní.
\end{abstract}

\section{Klíčová slova}

taneční věda, Tanzwissenschaft, Dance Studies, nová choreografie, taneční dramaturgie

\begin{abstract}
The goal of this article is to present and to contextualise the genesis of Dance Studies in German (Tanzwissenschaft) and Anglo-American environments, and to introduce the fundamental argumentative principles in its formation as an independent academic field of studies. Close attention is paid to German dance studies specifics, its basic scientific approaches and modifications which significantly resonate in the local discourse. Consequently, the article takes a closer look at several specific theoretical concepts, which the authors of the presented essay consider the most essential.
\end{abstract}

\section{Key words}

Tanzwissenschaft, Dance Studies, new choreography, dance dramaturgy

Př́spěvek vznikl za podpory MŠMT ČR udělené UP v Olomouci (IGA_FF_2019_038_Aktuální tanečněvědný diskurz: Možnosti analýzy tanečního představení). 
Taneční věda je obor, který je v českém akademickém prostředí dosud jen velmi okrajově zastoupen, ačkoliv v zahraničí se jedná o již etablovanou, nadto dynamicky se rozvíjející interdisciplinární oblast. V rámci kontextualizace zkoumané problematiky bude proto nejdříve krátce představena geneze tohoto akademického odvětví v německojazyčném (Tanzwissenschaft) a angloamerickém prostředí (Dance Studies) a budou přiblíženy stěžejní argumentační principy při jeho formování coby samostatného univerzitního oboru. Detailněji se pak studie zaměří na specifika německé taneční vědy, na její základní vědecké přístupy, modifikace, a především na několik konkrétních teoretických konceptů, které v tamním současném diskurzu obzvláště rezonují. Cílem předkládané studie je představit a kriticky zhodnotit nejaktuálnější strategie a koncepty taneční vědy, které lze relevantně využít zejména při analýze tanečního představení.

\section{Taneční věda jako univerzitní disciplína: geneze, formování, etablování}

Taneční věda, či též taneční studia, ${ }^{1}$ patří v současnosti k jedné z nejdynamičtěji se rozvíjejících akademických disciplín. Zároveň se však jedná o obor poměrně mladý, jeho etablování coby samostatné teoretické univerzitní vědní oblasti spadá v angloamerické větvi do osmdesátých let 20. století, v německojazyčné pak dokonce do let devadesátých. ${ }^{2}$ Jeho konstituování úzce souvisí jak se společensko-politickými a tím rovněž kulturně-uměleckými proměnami posledních dvou dekád 20. století, tak se stěžejním akademickým obratem v oblasti humanitních věd od počátku sedmdesátých let 20. století. Ten byl výrazně postulovaný na jedné straně myšlenkami poststrukturalistických teorií, na druhé straně pak zvýšenou pozorností o kulturální studia, kritickou teorii a politiku identit, což mimo jiné podnítilo rovněž novodobý zájem o výzkum jednotlivých druhů umění coby ,jádra sociálních struktur"33 (WONG and GIERSDORF 2019: 4). ${ }^{4} \mathrm{~V}$ tanci

1 Český ekvivalent může implikovat více významů i obecnějšího rázu (např. chápání pojmu studia prostorově, jako tréninková místa tanečníků a choreografů). Zde je nazírán coby samostatná akademická vědní disciplína, která v rámci humanitních oborů zastává dnes hojně inklinovanou transformaci názvů oborů z původních „věd“ na otevřenější koncepty „studií“ - ze spřízněných oborů jsou to například divadelní, filmová nebo kulturální studia.

2 Jak bude později ještě blíže demonstrováno, diskurz formování taneční vědy v německé oblasti s přestávkami lemuje de facto celé 20. století. K jeho zintenzivnění dochází od šedesátých let, kdy se tanečněvědný výzkum profiluje v rámci divadelní vědy či dalších uměnovědných disciplín anebo vysokých uměleckých škol. Stejně tak se postupně prosazuje též formou založení specificky tanečního vydavatelství (Ballet-Bühnen-Verlag v Kolíně nad Rýnem) a periodik (ballet international, později tanz international) či odborně tanečních fór a Rady pro tanec. V centru naší pozornosti však stojí moment, kdy se taneční věda etabluje jako svébytný univerzitní, ryze teoretický obor, přičemž vycházejíce z německého terciárního vzdělání v oblasti umění i my zde v tomto ohledu rozlišujeme mezi Hochschule (coby umělecké, výrazně na praxi orientované instituce) a Universität (instituce, kde se cizeluje teoreticko-analytický a historiografický vědecký diskurz tance).

3 Není-li uvedeno jinak, jsou veškeré překlady cizojazyčných citací pracovním překladem autorek studie.

4 Poststrukturalistické teoretické paradigma podnítilo také nové otázky vztahující se k povaze psaného textu, řeči a řečových aktů, jež destabilizovaly dosavadní status a funkci psaných a orálních událostí (AUSTIN 2000). Současně vzrostl v soudobých teoretických konceptech všeobecný zájem o tělesnost a angažovanou pozici pozorovatele - ve všech případech se jedná o způsob teoretického myšlení, jenž otevřel široký prostor pro zkoumání pohybu a tance, a tudíž též pro rozvoj tanečních studií jako takových. 
tento posun $\mathrm{k}$ teorii doprovázel obrat „od moderního akcentování specifické techniky a exprese směrem k postmodernímu zkoumání možností choreografie, v níž jsou zároveň přítomny vlastní ontologická podstata tance i akt ztělesnění, respektive tělesnosti coby centrálního tématu tance samotného" (WONG and GIERSDORF 2019: 4). Etablování taneční vědy jakožto a priori interdisciplinárního oboru, s vlastním předmětem zkoumání a specifickými metodologickými otázkami, probíhalo v tomto období za přispění teoretiků a historiků spř́íněných univerzitních oborů, zejména historie a divadelní historiografie, literárních, filmových a mediálních studií, a zejména v angloamerické oblasti pak v úzkém sepětí s etnografií, již zmiňovanými kulturálními studii a obdobně novodobě emancipovanými postkoloniálními studii. ${ }^{5}$

Vize vytvořit vlastní teorie tance a zasadit jeho výzkum do akademického prostředí jsou však mnohem staršího data a epistemologicky de facto spoluformují období taneční moderny. V USA vstoupil tanec do univerzitního prostředí nejdříve jako součást pedagogické metody, jako možnost učení se a poznávání prostřednictvím konání (LEIGH FOSTER 2013: 25). John Dewey, profesor Kolumbijské univerzity, tuto metodu včlenil do své výuky již od roku 1904 a konsekventně ji dále rozvíjel až do své smrti v roce 1930 (LEIGH FOSTER 2013: 25). Dewey v tanci spatřoval jeho dvojí kvalitu coby vitální formu exprese a médium porozumění zároveň. Zapojení tance do univerzitního kurikula pak obhajoval jako specifickou formu procesu poznávání. Blíže tento proces ve své studii „Dancing and Theorizing and Theorizing Dancing“ specifikuje americká choreografka a taneční teoretička, Susan Leigh Foster (2013), přičemž se

nejednalo nutně hned o určitý způsob teoretizování, ale zajisté o způsob zkoumání a objevování rozličných fenoménů. Posluchači, převážně samotní tanečníci a choreografové, tak poprvé na svém vlastním těle prozkoumávali Deweyho stěžejní myšlenku, že prostřednictvím různých tanečních technik a pohybových praktik se taneční umění otevírá jako nové osobité médium pro porozumění okolnímu světu. Hodiny taneční praxe byly prokládány kurzy z taneční kompozice, historie, filozofie a cross-kulturální analýzy, přričemž nabyté vědomosti se zpětně uplatňovaly při jejich zainvolvování do hodin vlastní taneční tvorby. (LEIGH FOSTER 2013: 26)

Tato trajektorie pro rozvoj tance v rámci univerzitního prostředí umožnila nazírat jej jako specifickou formu výzkumu, zároveň však otevřela v angloamerickém kontextu nadále velmi diskutované dilema týkající se vztahu tance a psaných diskurzů. Jak Leigh Foster v citované studii dále podotýká, „stěžejním se pro tuto debatu stal především argument, že tanec je sice jedinečným individuálním způsobem, jak poznávat a objevovat svět, v němž žijeme, ale že není možné tuto zkušenost adekvátně popsat či analyzovat. Proces tančení a vytváření tance může být prrímo zakoušen, ale nelze jej zprostředkovat verbálně“ (LEIGH FOSTER 2013: 26). Leigh Foster označuje tento postoj za de facto „anti-intelektuálni“, nebot’ „na jedné straně protežoval tanec jako autonomní pole bádání, jehož odlišnost od jiných výzkumných oblastí obohacuje kánon univerzit- 
ního vzdělávání. Na druhé straně zkonstruoval nesouměřitelné rozdíly mezi tancem a jinými vědními disciplínami a studium tance, respektive studium prostřednictvím tance, v podstatě od ostatních věd segregoval“ (LEIGH FOSTER 2013: 26). Na tomto univerzitním pozadí na počátku 20. století se zároveň zrodila jedna z nejstěžejnějších debat pro oblast tanečních studií v angloamerickém kontextu směrem $\mathrm{k}$ jeho pozdějšímu etablování v osmdesátých letech: „Jak teoreticky uchopit vztah mezi živým tanečním představením a psanými texty, které tuto událost diskurzivně zprostředkovávají?“ (LEIGH FOSTER 2013: 26).

Také v německojazyčné oblasti se první počiny zteoretizování tance coby specifické kultury věděni (Wissenskultur) odehrávaly ruku v ruce s ryze německým ekvivalentem taneční moderny, výrazovým tancem (Ausdruckstanz), a formováním konceptu takzvaného tanečního divadla (Tanztheater), kterým německá taneční věda rozumí specifický žánr divadelního tance ${ }^{6}$ kombinující principy choreografické a režijní práce. Odlišně od amerického kontinentu zde byly základy moderního teoretického myšlení o tanci položeny prostřednictvím tří tanečních kongresů, ${ }^{7}$ na nichž se shromáždily stovky tanečníků, choreografů, tanečních pedagogů, kritiků, ale i divadelníků, hudebníků a nadšenců, aby všichni společně diskutovali otázky a problémy týkající se soudobého tanečního diskurzu. Právě na těchto kongresech promluvil vídeňský architekt Adolf Loos o nutnosti návratu tance k přirozenosti („,nohy již nesmějí být - jako v některých pozicích klasického baletu - navzájem překřížené, ale musí stát paralelně a zcela přirozeně vedle sebe“ (VÖLCKERS 2007: 9), Oskar Schlemmer uvedl svůj Triadický balet a zdůraznil význam abstrakce v tanci - „chaos dnešní doby je velký až až, proto je nezbytně nutné, opírat se o zákony prostoru, barvy a formy" (VÖLCKERS 2007: 9), Mary Wigman deklarovala vlastní vizi absolutnosti tance, když požadovala „dobytí divadel prostřednictvím tanečního gesta" (VÖLCKERS 2007: 9), a Rudolf Laban, první teoretik moderního tance vůbec, zde představil svůj koncept kinetografie, notačního systému pro záznam a analýzu lidského pohybu (VÖLCKERS 2007: 9). Jedním z resultátů druhého tanečního kongresu v Essenu v roce 1928 byl pak zrod idey na založení vysoké taneční školy a vytvoření vědecko-sociologického centra pro výzkum pohybu, což byly první pokusy o institucionalizaci dosavadních poznatků a vědění o tanci. $V$ této souvislosti bezprostředně po skončení tohoto kongresu začal vycházet čtvrtletník s programovým titulem Schrifttanz jakožto koncept archivace a prostředek rozvoje taneční analýzy, tanečního vzdělávání

6 V německé taneční vědě se v současnosti užívají tř̌i, do jisté míry se vzájemně překrývající, pojmy: umělecký tanec (künstlerischer Tanz), jevištni tanec (Bühnentanz) a divadelni tanec (Theatertanz). Právě poslední zmiňovaný je v aktuálním tanečněvědném diskurzu nejvýrazněji akcentovaný, nebot imanentně odkazuje rovněž na sebereflexivní kritiku tanečního umění coby součásti (divadelní) instituce, která je od dob konceptuálního obratu v tanci na úrovni praktické i teoretické hojně tematizovaná (např. HUSEMANN 2009). S ohledem na zacílení této studie jej proto přejímáme i my. Zároveň bychom tak chtěly znovu upozornit na nepřesnosti, které v českém diskurzu označování tanečního umění v souvislosti se zaužívaným termínem tanečni divadlo neustále přetrvávají. Taneční divadlo, coby doslovný překlad pojmu Tanztheater, implikuje výhradně jeden ze specifických dispozitivů tance v německé taneční historii 20. století. Ten směřoval od konceptu Tanztheateru Kurta Joosse v období meziválečného expresionistického výrazového tance k poválečné generaci německých choreografů a choreografek, jež na odkaz meziválečného Tanztheatru explicitně navázali. Mezi nejvýraznější reprezentanty zajisté patři Pina Bausch se svým souborem Tanztheater Wuppertal.

První se konal v roce 1927 v Magdeburgu, druhý 1928 v Essenu a třetí 1930 v Mnichově. 
a tanečního výzkumu. $\mathrm{V}$ důsledku zhoršujících se dobových politicko-společenských okolností v Německu na počátku třicátých let však tento projekt institucionalizace tance zůstal utopií a ani vydávání tanečního periodika nemělo dlouhé životnosti - Schrifttanz vycházel pouze do konce roku 1932, tedy jen čtyři roky.

Na tradici tanečních kongresů Výmarské republiky explicitně navázal v roce 2006, v době exponenciálně vzrůstajícího zájmu o taneční umění coby specifického druhu lidského vědění a poznání, taneční kongres s příznačným mottem Wissen in Bewegung [Vědění v pohybu], pořádaný v Berlíně v Haus der Kulturen der Welt. Celkem na 1700 mezinárodních účastníků rozličných profesí a vědních oborů se zabývalo praktickými i teoretickými otázkami oscilujícími mezi termíny tanec a vědění: „Co chceme my a co chce společnost vědět o tanci a prostřednictvím tance? Co se musí vědět, aby se mohlo tančit? Co víme my, když tančíme? Co ví tanec o nás, co ani sami nevíme, nebo jen tušíme, anebo jsme už zapomněli? Jak můžeme toto vědění tance per se zasadit v pohyb?“ (VÖLCKERS 2007: 10).

Až neočekávaně silná rezonance tohoto kongresu, jehož nejdůležitější výstupy jsou shrnuty ve sborníku Wissen in Bewegung. Perspektiven der künstlerischen und wissenschafltichen Forschung im Tanz (2007), definitivně potvrdila novodobý širokospektrální zájem o tanec nejenom jakožto vlastní umělecké formy, ale i samostatné vědecké disciplíny. Od devadesátých let 20. století výrazně vzrostl i na jiných evropských univerzitách tanečněvědný diskurz, ale teprve zřízení samostatné profesury v oblasti taneční vědy na Freie Universität v Berlíně v roce 2003 „významně přispělo k jeho současné profilaci a možnosti studovat tento obor na univerzitě na ryze teoreticko-vědecké bázi bez návaznosti na praktická cvičení a pravidelný fyzický trénink “ (PAVLIŠOVÁ 2018: 7). Další iniciativou, zasluhující se o dynamický rozvoj taneční vědy v německojazyčné oblasti, byl pětiletý program tzv. Tanzplan Deutschland 2005-2010, zaštítěný Německým nadačním fondem pro kulturu [Kulturstiftung des Bundes]. Ten se exaktně orientoval na výstavbu strukturovaných podmínek a podpory tance a jeho diskurzů, čímž zároveň stimuloval nutnost specifického vědění o tanci, a tím další etablování taneční vědy. Tato iniciativa nepodpořila jenom toliko potřebné obecně veřejné povědomí o tanci, ale vytvořila i okruh pozitivního „nedostatku věděni o tanci, a tím základní aparát pro vlastní tanečněvědné zkoumání a jeho validaci coby samostatného diskurzu“ (IMBRASAITE 2016: 372).

Současný tanečněvědný diskurz z globální perspektivy v sobě pojímá tři primární, vzájemně provázané oblasti zkoumání: 1) tanec jako metoda a dějiště politické agendy; 2) taneční praxe jako výzkum a 3) ontologie tance. Za účelem založení tanečních studií jakožto samostatného univerzitního oboru pracovala první výrazná generace akademiků (Susan Leigh Foster, Mark Franko, Randy Martin, Susan Manning, Ann Cooper Albright ad.) s tancem a choreografií spíše coby metodou než vlastním objektem zkoumání. V jejich dílech se choreografie a tanec stávaly modely pro setkávání se, organizaci a destabilizaci politických, strukturalistických a postkoloniálních postulátů. Tento postup následně připravil široké metodologické pole pro obdobné zkoumání otázek týkajících se problematiky genderu, rasy, sexuality, národnosti a identity ve vztahu k politicky transgresivním možnostem tance. 
Strategický obrat směrem $\mathrm{k}$ teorii zároveň vědomě definuje taneční studia s plným respektem k samotnému aktu tančení:

$\mathrm{V}$ reakci na tento obrat $\mathrm{k}$ teorii začali zároveň taneční vědci re-formulovat taneční praxi jako výzkum koncentrovaný kolem otázek z oblasti fenomenologie, na tělo centralizovaného diskurzu a sociálně podmíněných aktivit. Tím chtěli především demonstrovat, jak již samy akty tančení v sobě imanentně obsahují potenciál rozrušit zažité akademické hierarchie zakládající se na opozičních aparátech teorie versus praxe. (WONG and GIERSDORF 2019: 5)

Praxe jako výzkum poskytuje rovněž podstatná řešení otázky týkající se logocentrismu v západní společnosti - onen fokus na řeč a psaný projev jako hlavní prostředek mezilidské komunikace - tím, že v rámci komunikace upřednostňuje bezprostřednost a účinnost lidské tělesnosti. Tento způsob chápání komunikace může zároveň akcentovat smyslovou zkušenost těla jako prostředku umožňujícího informovanější porozumění tanci nebo tomu, čím tanec může být.

Oproti bezprostřednosti a specifičnosti materiality tančících těl a agitujících možností choreografie se třetí přístup tanečněvědného zkoumání zabývá otázkami vlastní ontologie tance, tedy snahou pochopit, čím pro nás tanec jakožto univerzální kategorie je a jak strukturální porozumění tanci může přiblížit komplexnější chápání jiných sociálních, politických anebo i vědních struktur. Tato a priori imanentní političnost tance poskytuje možnost nazírat jej nejen v „tradiční“ kategorii estetiky, ale též jako médium politicko-společenských sil. Při analýze jednotlivých choreografických děl či technik pak při akcentaci tohoto tanečněvědného směřování není stěžejním cílem proniknout dovnitř nějakého specifického systému (doslova jej „prokouknout“), ale spíše zkoumat dané představení jako souhrnný a abstraktní diskurz filozofických, estetických a politických možností tance coby všeobecné kategorie.

Právě třetí jmenovaný způsob tanečněvědného akademického zkoumání je výrazně akcentovaný v námi zkoumané německojazyčné oblasti. Zaměřili se na něj hned první teoretici a zejména teoretičky tance (Gabriele Brandstetter, Sabine Huschka, Gabriele Klein, Katja Schneider, Gerald Siegmund, André Lepecki $\left.{ }^{8}\right)$, kteří od devadesátých let usilovali o etablování taneční vědy coby samostatné vědní disciplíny. A jak pro nás vyplynulo bližší koncentrací na dílčí studie a antologie ${ }^{9}$ vztahující se k problematice výzkumu tance a možností metodologického uchopení jeho analýzy, je jeho inherentní součástí dodnes.

V následující části této studie proto představíme několik vybraných konceptů a per-

8 André Lepecki je americký taneční vědec, který se ve svém výzkumu výrazně zaměřuje na otázky, koncepty a metodologická rozhraní, explicitní pro německojazyčnou větev taneční vědy. Zejména politická ontologie tance tvoří centrální fokus jeho zkoumání (viz LEPECKI 2006). Přímo kolegy z amerických tanečních studií je pak pravidelně usouvztažňován a přiřazován $\mathrm{k}$ evropským vývojovým tendencím tanečněvědného diskurzu.

9 Kromě výše zmíněných vlastních jmen jsme se blíže zaměřily na sborníky Wissen in Bewegung: Perspektiven der künstlerischen und wissenschaftichen Forschung im Tanz (2007), Dance [and] Theory (2013) a Methoden der Tanzwissenschaft. Modellanalysen zu Pina Bauschs ,Le Sacre du Printemps/Das Frühlingsopfer‘ (2015), které lze dnes již považovat za základní referenční osu tanečněvědného zkoumání. 
spektiv německé taneční vědy, kterými je současný výzkum výrazně ovlivněn a veden a jež spoluutváří jeho základní premisy a teze. Ačkoliv čerpáme z konkrétních, námi vybraných antologií, jsme si velmi dobře vědomy, že německojazyčný diskurz o metodách tanečněvědného výzkumu je rozprostřen v širokém spektru dalších monografií a sborníků, které nelze považovat za pevně daný tanečněvědný kánon. V německojazyčném prostředí se na téma divadelního tance udržuje živý dialog a není možné sáhnout po jedné shrnující publikaci, která by vymezovala základní otázky taneční vědy jakožto vědního oboru, navíc s ohledem na otázky a výzvy, které kladou nejsoučasnější poznatky humanitních a sociálních věd a filosofie. Snad již v dnešní době, nabízející stále nové perspektivy, není možné a ani by nebylo žádoucí tento živý dialog definitivně utnout. Možnou cestou je jej mapovat a postupně strukturovat, modifikovat či dalšími (interdisciplinárními) prizmaty dále rozvíjet.

\section{Tanec jako specifický akt vědění}

Pojetí choreografického procesu a samotného aktu tančení coby specifické kultury vědění je v současné německé taneční vědě úzce propojeno se sociologickou perspektivou nazírání tance, kterou zastává např́íklad jedna z čelných reprezentantek tohoto oboru, Gabriele Klein (2007, 2013). Jakékoliv vědění, tedy i to taneční, není člověku vrozené a ani není součástí mentálního či tělesného stavu určitého subjektu. Vzniká a formuje se vždy v různých sociálních praktikách, a proto je nezbytné akcentovat vlastní výzkum tance také na pozadí těchto sociálních kontextů.

V globalizovaném světě 21. století je status „vědění“ klíčem k blahobytu, vlivu a moci. Vědění je zásadní pro vytvoření světonázoru, pro vzájemné porozumění mezi lidmi a koneckonců i pro zdůvodnění stěžejních sociálních, politických, kulturních a ekonomických vztahů. A také odjakživa velmi dobře platilo, že kdo ví, má i moc, ač se nemuselo vždy jednat o někoho, kdo skutečně „věděl“, stačilo, že disponoval možností dostat se k určitým informacím a modelům dobového myšlení a poznání a zneužít je ve vlastní prospěch. ${ }^{10}$ Snaha taneční vědy zasadit tanec do aktuální debaty nad stavem dnešního vědění a poznání znamená etablovat jej v rámci politických, společenských a estetických diskurzů, protože - jak dokládají nejrůznější kulturně-politické konsekvence - tanec nejen coby umění, ale i jako součást popkultury byl dlouhou dobu až fatálně marginalizován. Tato dlouhodobá deficitní (ne)př́ítomnost a reprezentace tance v politice, vědě a médiích je minimálně zarážející, nebot tanec byl vždy zároveň považován za velmi signifikantní uměleckou formu a projev určité kultury pohybu. Jako patrně žádné jiné médium byl (a dosud je) nejvýraznějším tělesným projevem sociální zkušenosti dané doby a důležitým aktem vědění pro obecnou kulturní pamět. Gabriele Klein uvádí, že v této souvislosti můžeme mluvit o takzvaných

10 Např́iklad církevní moc ve středověku, mocenské aparáty diktátorských režimů, nebo rovněž, jinak uchopeno, moc médií v globalizované mediální společnosti. 
tělesných diagnózách doby, které umělecký tanec analyzuje a zprostředkovává na esteticko-reflexivní úrovni. A od doby moderny se tato estetická rovina stále více stávala rovněž rovinou kritiky - převážně tradičních estetických konceptů, společnosti a kultury. Je-li z hlediska této perspektivy tedy výrazový tanec 20. let koncipován jako diagnóza doby tematizující technizaci, fragmentarizaci a vzájemné odcizování se industrializované společnosti a Tanztheater 70. let kritikou společenských mocenských vztahů, pak dispozitiv současného tance na počátku 21. století je již přímo ukotven a propojen s kontextem soudobé společnosti vědy a vědění. (KLEIN 2007: 28)

Tomu odpovídají i různorodé estetické koncepty těchto dispozitivů: Zatímco výrazový tanec ještě proklamoval návrat k přírodě a organickou zkušenost těla jakožto společenskou alternativu, směřoval Tanztheater již k přímému průniku těl a společensko-politických aparátů moci. Od devadesátých let se tanec stává stále více sebereflexivním procesem a až analyticky vědeckým zpo̊sobem se zabývá tématy, jako jsou identita a kulturní odlišnost, tělo a jazyk, a to nejen v podmínkách svého vlastního média, ale i obecněji coby produkt moderní společnosti a kultury (KLEIN 2007: 28).

\section{Fluidnost a (ne)diskurzivita jako vlastní ontologická podstata tance}

Pro kteroukoliv společnost platí, že jí generované vědění nezůstává staticky dané, ale neustále se proměňuje. Permanentní fluidní povaha společnosti současně spoluvytváří jí vlastní, nové vědění, potlačující to předchozí, které je spoluzodpovědné také za to, že se mohou rozvíjet a etablovat nové mocenské strategie a může docházet k rozdělení těchto mocí na úrovni státu a společnosti. Ona fluidnost a tranzitornost jsou však rovněž signifikantními znaky tance per se, čímž se povahy obou těchto kreativních oblastí lidských aktivit vzájemně přibližují a protínají. Teprve když začal být tento aspekt akcentován v rozličných disciplínách humanitních věd, ${ }^{11}$ začala se stále více diskutovat otázka, jaké specifické vědění, a prostřednictvím čeho, vytváří a zprostředkovává tanec.

Bylo by však příliš zjednodušené, kdyby se význam tance ve společnosti věděni (Wissensgesellschaft) redukoval pouze na metaforickou rovinu fluidnosti a tranzitornosti, protože tanec sám, ač mnohdy nediskurzivně, může implikovat a transformovat určitou formu (tanečního) vědění. Francouzský filozof Jean-François Lyotard (1984) rozlišoval dvě základní formy vědění: narativní, které se vztahuje na oblast vyprávění a implicitně legitimizuje sebe sama, a diskurzivni coby specifická forma vědění, jež se produkuje především skrze vědu a vyžaduje explicitní legitimizaci. Pro tanečníky je pak taneční vědění určitým druhem vědění, „které se zakládá na vlastní tělesné zkušenosti

11 Sociolog Erwing Goffman již v sedmdesátých letech 20. století definoval svůj koncept „choreografií sociálního“, v němž se zaměřil na zautomatizované tělesné kognitivní aktivity, které člověk coby „strukturované improvizace“ vytváří v každodenních situacích, aniž by o nich zvláště přemýšlel (obsluha kávovaru, čištění zubů, tělesné interakce ve veřejných dopravních prostředcích atp.). Goffman pro výklad svého konceptu používal další analogické příměry k tanci, když o těchto aktivitách mluvil jako o malých rituálních tancích, vykonávaných kódovanými tělesnými pohyby a gesty. Více (GOFFMAN 1971). 
a je intersubjektivní, tedy zprostředkované tělesnou komunikací“ (KLEIN 2007: 32). Takovéto vědění lze na základě Lyotardova konceptu považovat za specificky narativní. Specificky do té míry, pokud je narace zprostředkována pouze těly, a nikoliv verbálně. Tělo nemluví, ale jedná. A právě tento systém ukazování nefunguje jako logika řeči na základě ambivalence výpovědních hodnot „bud'-anebo“. Toto „ukazování tělem“, jak poukázal německý mediální vědec Dieter Mersch, znamená „ne-identické“ (KLEIN 2007: 32$).^{12}$

To, že tělo disponuje strukturou ukazování, a nikoliv jazykovou, je pro tanečněvědné oborové zkoumání jednou z největších výzev, a to zejména v konceptech vztahujících se k teoriím poznávání, protože na rozdíl od vlastní taneční praxe produkuje určité diskurzivní vědění, zprostředkovávané - opětovně - jazykem (KLEIN 2007: 33). Z této perspektivy vzato je taneční věda současně kritikou stávající vědy, protože se obrací proti takovému statutu vědění, které se snaží tyto dynamické procesy „myšlení pohybem“ překrýt statickými (jazykovými) koncepty.

Vědění, které se prostř̌ednictvím tance a choreografie ukazuje a přenáší, je především tělesně-smyslové a implicitní a je zprostředkováno kineticky i kinesteticky zároveň. Pokud je tedy tanec vnímán a akceptován jako specifická kultura vědění, pak zásadním způsobem posouvá hranice toho, co jsme dosud považovali za vědu a jí generované vědění, a tím rovněž uvádí v pohyb samotné naše dosavadní chápání toho, co to vědění je. Tento taneční vědou fokusovaný dynamický a kontingentní vztah pozorovatele a pozorovaného předmětu lze nadto efektivně využít $\mathrm{i} v$ jiných vědeckých oblastech a samotném výzkumném procesu, a to i u těch disciplín, které se zabývají zdánlivě výhradně fixovanými objekty a „spolehlivě“ verifikovatelnými výsledky. Taneční věda se tak může stát inspirativní dynamickou reflexí, která v mnoha ohledech narušuje dosavadní rámcové podmínky vědeckého bádání, například přiznáním, že rovněž tělesný pohyb, smyslovost nebo určité emoce výzkumníka mohou spoluovlivňovat proces produkce následného poznání a vědění.

\section{Choreografie jako kritická praxe}

Od devadesátých let 20. století, v souvislosti s takzvaným konceptuálním obratem, ${ }^{13}$ začínají být v oblasti taneční vědy tanec a choreografie stále explicitněji nazírány jako kritická praxe, jako specificky ztělesněná političnost. Ne náhodou se tak děje v době, kdy

\section{Více viz (KLEIN 2007: 32-33).}

13 V devadesátých letech dochází v oblasti uměleckého tance k radikální změně paradigmatu (či též: dispozitivu), která se záhy v jeho percepci i kritické reflexi začíná etablovat pod pojmem konceptuální tanec. Jedná se o vývojovou tendenci tance, u níž pro všechny její představitele platí dvě specifické koherentní vlastnosti: propojování myšlení/vědění s taneční praxí a fakt, „že se v něm stále méně tančí. Konceptuální tanec, či též tanec-koncept, předkládá v dílech jednotlivých tvưrců především rozšířený vztah chápání pojmů tanec a choreografie jako formující se podoby meta-tance, čili tance diskurzů, respektive se stává určitým meta-diskurzivním dispozitivem. Na základě absence tanečního tělesného pohybu v jeho tradičním vnímání minimálně v západní kultuře se pak choreografie o to více stává médiem kritické reflexe obrazů a konceptů těl a podob jejich tradiční divadelní reprezentace. Více (PAVLIŠOVÁ 2018: 16-21). 
se radikálně začíná proměňovat především sama společnost. ${ }^{14}$ At již se jedná o disertaci Pirkko Husemann Choreographie als kritische Praxis [Choreografie jako kritická praxe] (2009), teorém „političnosti ztělesnění“ Susan Leigh Foster, „teorii mobilizace“ Randyho Martina, nebo „topos kinestetické političnosti“ André Lepeckiho, ${ }^{15}$ všechny tyto koncepty identifikují choreografickou praxi jako kritickou, a tedy imanentně politickou. Nejenom že jsou tyto koncepty per se paradigmatické pro kontextualizaci tehdy stále ještě poměrně mladé vědecké disciplíny taneční teorie coby kritické teorie, potažmo politické filozofie tance, ale zároveň také pro obrat k teorii v samotné taneční praxi. ${ }^{16}$ Mnozí z tanečních teoretiků ${ }^{17}$ byli totiž současně úzce propojeni s taneční praxí - jako choreografové, dramaturgové, tanečníci nebo performeři - a zasloužili se tak o ojedinělou transformaci proměn toho, jak se o tanci, choreografii a teorii přemýšlí a jak se následně přímo praktikují. Dřívější dichotomický vztah teorie a praxe je zde rozpuštěn a stává se více fluidním. A taneční teorie se tak stává takzvanou teorií praxe, tedy teorií, která primárně necílí na výsledný produkt, ale především na samotný proces tvorby, například na reflexi užitých choreografických strategií nebo formy kolaborace mezi jednotlivými členy daného souboru. Společným prizmatem takto specifikovaných teoretických konceptů je pak definice sebe sama jako „výzkumu zkušenosti“, „vědy skutečnosti“ či „praktické vědy“ (KLEIN 2013: 138). Vlastní teoretický aparát se tedy nachází na rozhraní umělecké a vědecké praxe, jejich vlastních forem vědění a metod reflexe.

Praxe v choreografii definovaná jako „kritická“ v současném tanečněvědném nazírání neznamená výklad slova „kritika“ v jeho klasickém kantovském pojetí, tedy „soud, úsudek či obecně posuzování“ (KLEIN 2013: 139), ale specifický modus konání, jež generuje další poznání. Vycházeje z premis především Judith Butler a Michela Foucaulta chápe tato tanečněvědná perspektiva kritickou praxi jako praxi ohledávající a narušující limity, které způsobují naše navyklé formy myšlení, přičemž při analytickém zkoumání takto nazíraného pojetí tance se využívá zejména tří hlavních aspektů: 1) koncept praxe, 2) sféra kritiky 3) rámec, respektive systém, v němž se vykonává. Jak píše Butler v jednom ze svých esejů: „Kritika je vždy kritikou nějaké ustanovené praxe, diskurzu, epistémé, instituce, a ztrácí svůj charakter právě v tom momentě, kdy je vyjmuta ze svého konání a postavena jako generelně zobecnitelná praktika“ (BUTLER 2002: 212; KLEIN 2013: 139).

Konkrétní umělecké strategie jsou pak kritické v tom slova smyslu, že v rámci specificky strukturovaného prostoru z(a)koušejí nové formy komunikace, společenství, dění nebo samotného procesu tvorby, čímž se současně stávají jak polem kritické umělecké praxe, tak „experimentálním polem alternativních sociálních praktik“ (KLEIN 2013: 139), a jsou tudíž a priori politické. Na rozdíl od kantovského soudu, který se uplatňuje

14 „Globalizovaná společnost, bezuzdný kapitalismus, domnělé skoncování s třídní společností, konec sociálního státu/státu blahobytu či neoliberální politika je jen několik klíčových slov, opakovaně užívaných k charakterizaci těchto sociálních změn a k výkladu establishmentu post-fordovské politiky“ (KLEIN 2013: 137).

15 Více k těmto konceptům viz (KLEIN 2013: 139, 147-148).

16 Často ruku v ruce jdoucí s tendencemi sloučenými pod výše zmiňovaným pojmem konceptuálni tanec.

17 Za všechny jmenujme alespoň Marianne Van Kerkhoven, Bojanu Kunst, Bojanu Cvejić či Anu Vujanović. 
uvnitř již stanovených kategorií (například pojmy klasický, moderní, současný), kritika v butlerovském, respektive foucaultovském, slova smyslu operuje s tím, jak přesně a na základě čeho je daná kategorie konstituována - např́́klad oblast současného tance ve vztahu k jeho historickým epistémé, případně dílčím dispozitivům. Kritická praxe zkoumá možné principy konstituce a schémata myšlení, která spoluurčovala vytvoření takové kategorie. Z těchto premis vyplývá, že vlastní rámec, respektive systém, v němž se taneční kritická praxe vykonává, musí reflektovat aktuální struktury myšlení, formy vědění a poznávání vždy na pozadí historických proměn a epistemologických krizí tance, jež jsou současně odrazem sociálních rámců a řádů dané doby.

Ze sociologické perspektivy, $\mathrm{v}$ taneční vědě zejména hojně užívané praxeologie Pierra Bourdieuho, je „teorie praxe“ současně koncipována jako „ztělesněná kolektivní znalost: jako mimeticky a performativně produkovaná znalost na základě konkrétních, specifických praktik, která může být vždy zakoušena pouze jako senzuální, tělesná, emergentní, tekutá a časově omezená“ (KLEIN 2013: 142). Je vždy utvářena inkluzí a exkluzí jiných možností a relací, které jsou predestinovány vzájemnou konfrontací, a jejíž výsledek není a priori předurčený.

\section{Tanec/pohyb myšlení - dramaturgie v nové choreografii}

Jedním ze současných fenoménů, spojených s produkcí současného tance a tanečních či pohybových performancí, pro které rakouský taneční teoretik Helmut Ploebst (2001) nabízí pojem nová choreografie ${ }^{18}$, je taneční dramaturgie, do níž je imanentně otištěna vzájemná nevyhraněnost kategorií teorie a praxe (něm. Tanzdramaturgie, angl. dance dramaturgy/dramaturgy of dance). Jakožto novou choreografii lze chápat taková performativní díla, jejichž hlavním těžištěm, estetickým východiskem a výrazovým prostředkem je tělo a které lze charakterizovat jakožto „inscenované řazení těl v časoprostorových texturách“, jenž je „reflexivním procesem“ (PAVLIŠOVÁ 2018: 19). Takové nediskurzivní umělecké formy lze označit také jako tělesné formy uměleckého vyjádřeni (body-based forms of artistic expression), což je jedno z označení objevujících se v anglojazyčném tanečněvědném diskurzu. Autoři a autorky se jím vypořádávají s formální různorodostí pohybových uměleckých děl, jejichž společným východiskem je práce s tělesností.

Taneční dramaturgie, odhlédneme-li od zarážejícího paradoxu, které spojení pojmů tanec (praxe těla) a dramaturgie (ze starořeckého dramaturgia, tedy umění skládat divadelní hry; v divadelní produkci lessingovsko-brechtovské tradice praxe textová a diskurzivní) nese, a zamyslíme-li se spíše nad tím, jakou informaci označení tanečni dramaturgie implicitně přináší, lze zjistit, že v širším slova smyslu se jedná o zapojení analyticko-kritických praktik do taneční a pohybové umělecké praxe. Tedy o spojení myšlení a uměleckého tance/pohybu. Praxe myšlení, odehrávající se v tvůrčím choreografickém

18 Více k pojmu nová choreografie viz (PLOEBST 2001), kde v závěrečné kapitole analyzuje choreografickou tvorbu tehdy současné generace etablovaných choreografů a choreografek, mimo jiné čelných představitelů konceptuálního tance (Jérôme Bel, Xavier Le Roy, Vera Mantero, Meg Stuart, Boris Charmatz, Benoît Lachambre, Raimund Hoghe, Emio Greco/PC, João Fiadeiro). 
procesu, má svá specifika, která jsou zde naznačena naší metaforou tanec/pohyb myšlení, jež odkazuje primárně na flexibilitu a otevřenost $\mathrm{v}$ přemýšlení o vznikajícím díle a na podporu přirozené dynamiky tvůrčího procesu.

Toto uchopení taneční dramaturgie vychází z osobitosti tvưrčích strategií tělesných forem uměleckého vyjádření, v nichž je důraz kladen převážně na proces vzniku choreografického díla. Je důležité si uvědomit, že dehierarchizací pozic a experimentováním s modely organizování v rámci tvưrčího procesu se na aktuálním poli současného tance stále častěji setkáváme se situací, kdy autorství choreografického díla náleží de facto všem podílejícím se na jeho tvorbě. $\mathrm{V}$ extrémních případech se tak v anotacích tanečních děl v kolonce choreografie objevuje slovo „kolektiv“ či jiný podobný výraz označující celou skupinu tvůrců. $V$ těch méně extrémních př́ípadech pak zůstávají pozice navenek stále striktně oddělené, ovšem v realitě samotného tvưrčího procesu jde, co se týče formy spolupráce, spíše o vzájemnou souhru než hierarchizovanou organizaci $\mathrm{s}$ jasně definovanými úkoly pro každého z tvưrců, jež řídí choreograf, nesoucí hlavní zodpovědnost za výsledné dílo. Stále častěji lze na scéně současného tance pozorovat kolaborativní systémy spolupráce, přičemž choreograf často nepřichází s hotovou pohybovou partiturou a víceméně fixní představou o výsledné podobě choreografie, které se s pomocí tanečníků a dalších podílejících se tvưrců snaží přiblížit. Daná představa o díle se rodí, vyvijí a dynamicky mění až, a právě, během tvưrčího procesu, který je tedy mnohem spíse procesem aktivní kreativní tvorby než procesem zkoušení již fixní ideje. Pokud je v takovém tvůrčím procesu přítomen dramaturg (jenž není nezbytný ${ }^{19}$ ), představuje vedle ostatních jen jednu dílčí hybnou sílu, která ovlivňuje dynamiku tvưrčího procesu stejnou měrou jako intenzity choreografa, tanečníků a dalších tvůrců (např. sounddesignér, lightdesignér, scénograf aj.). Dramaturgovy schopnosti kontextualizovat, konceptualizovat a stratifikovat vznikající svět díla a možnosti pracovat $\mathrm{s}$ jazykem, myšlenkami, př́padně s teoriemi nejsou v rámci tvorby uplatňovány mocensky ani didakticky, ale mnohem spíše za účelem podpory a péče o tvưrčí proces a jeho dynamiku. Svou praxi pojmenovávají dramaturgové a dramaturgyně, jež zároveň spoluvytváří teoretickou bázi této stále akcentovanější disciplíny, různými způsoby. Bojana Bauer (2015) mluví o tvưrčím procesu jako o těle, jehož je dramaturg nedílnou součástí, Maaike Bleeker (2015) popisuje dramaturgickou spolupráci jako mapování myšlení-mezi. Sandra Noeth (2011) zase upozorňuje na úlohu dramaturga jakožto pisatele protokolů tvưrčích setkání, k nimž je možné se kdykoliv vrátit, přičemž její stanovisko

19 To je dáno tím, že pozice dramaturga není v produkci současného tance institucionalizována, jako je tomu v divadelní produkci, v níž je dramaturg jakožto ten, kdo v lessingovském duchu spoluurčuje a hlídá zvolenou ideu díla, pevně zakotven. Naopak strach z institucionalizace dramaturga, a tudíž i z př́lišného svázání tvưrčího procesu diskurzivními praktikami a jednostranným privilegovaným věděním vedl v devadesátých letech $\mathrm{k}$ interním debatám mezi teoretiky a praktiky současného tance. Obavy z institucionalizace autoritativního dramaturga v taneční praxi shrnuje ve svém polemickém textu Anxious Dramaturgy (2003) kritička, dramaturgyně a badatelka Myriam van Imschoot. Důsledkem je, že v praxi současného tance lze uvažovat o tzv. ztělesněné dramaturgii v postavě konkrétního dramaturga či dramaturgyně, která se na procesu tvorby podílí, a o dramaturgii jakožto imanentní součásti choreografické tvorby. Ta se může v procesu vyjevovat jednak v podobě konkrétních praxí, které pohání tvưrčí proces kupředu a pečují o něj, jednak v podobě nutnosti kriticky nahližet vytvořený materiál a rozhodovat, zda zůstane součástí díla či nikoliv. 
rozvíjí zmíněná Bojana Bauer (2015), která chápe dramaturga také jako ztělesněný archiv tvůrčího procesu. Bojana Cvejić (2015) nazírá dramaturgii v současném tanci jakožto přátelství s problémy.

Neméně důležité je pro tvůrčí proces z dramaturgického hlediska i hledání vztahů se společensko-politickými podmínkami a kontexty, a tudíž i možnost, aby dramaturg vědomě spojoval mikroroviny tvorby a díla s jeho makrorovinami. Ty spatřuje nizozemská taneční a divadelní dramaturgyně Marianne Van Kerkhoven v okruhu kolem tvưrčího procesu, přičemž pro hranice mezi jednotlivými rovinami volí metaforu pokožky, která dýchá a do jisté míry tyto zdánlivě nepropustné hranice překonává:

\begin{abstract}
Mikrodramaturgii můžeme definovat jako zónu, strukturní kruh, který zaujímá nitro a [bezprostřední] okolí [divadelního či tanečního] díla. Inscenace však ožívá díky interakci, díky svému publiku, a díky všemu, co se děje mimo její vlastní orbitu. Okolo inscenace stojí také divadlo a okolo divadla leží město a okolo města, tak daleko jak dohlédneme, je celý svět, a dokonce i nebe a hvězdy. Zdi, které vyznačují linie všech těchto kruhů, jsou jako kůže, mají póry a dýchají. Na to se někdy zapomíná. (VAN KERKHOVEN 1994: 7)
\end{abstract}

Diskuze o taneční dramaturgii probíhá kontinuálně od devadesátých let minulého století. Existuje množství dílčích studií na toto téma, v západní Evropě bylo uspořádáno i několik konferencí. Od roku 2015 vyšla řada publikací, monografií i sborníků, které se snaží diskurz o taneční dramaturgii rozvíjet a v prostředí současného tance a taneční vědy etablovat. ${ }^{20}$ Výzkum o taneční dramaturgii je charakteristický svým rozkročením mezi teoretickým diskurzem a dramaturgickou praxí také proto, že autory a autorkami studií a monografií jsou velice často praktikující dramaturgové a dramaturgyně, které se snaží uchopit svou práci různorodými teoretickými či filosofickými koncepty. Lze říci, že nekončící dialog je pro specifikování taneční dramaturgie ve skutečnosti jedinou možností. Základem taneční dramaturgie je totiž v její institucionální zbytnosti různorodost ve zvolených metodách a přístupech, které jsou pro každý tvůrčí proces jedinečné a individuální. Podstatou je totiž myšlení v procesu o tvưrčím procesu, které je mu imanentní a vyrůstá z něho, nikoliv myšlení vedené a směřované primárně za účelem dosažení vytýčeného cíle. Metaforicky tedy spíše tanec/pohyb myšleni než taženi/ pochod myšlení.

20 Jako př́klad zde lze uvést tři publikace věnované výhradně taneční dramaturgii: monografii Dramaturgy in Motion: At Work on Dance and Movement Performance (2015) americké dramaturgyně Katherine Profeta, antologii Dance Dramaturgy-Modes of Agency, Awarness and Engagement (2015) Pil Hansen a Darceyho Callisona a monografii Bojany Cvejić Choreographing Problems (2015). Rovněž v roce 2015 vyšla monografie dramaturgyně Katalin Trencsényi Dramaturgy in the Making (2015), jejíž třetí část pojednává o taneční dramaturgii. Podstatný zdroj, který představuje pomyslný archiv vývoje myšlení (mimo jiné) o taneční dramaturgii, je webový portál SARMA, Laboratory for discursive practises and expanded publication, jehož vznik iniciovali v roce 2000 nizozemští badatelé Myriam Van Imschoot a Jeroen Peeters. Cílem portálu je utvářet jednotící platformu pro texty o současném tanci a performanci, které jsou jinak roztřrístěny do různých periodik, jako jsou např́klad Maska, Etcetera, Dance Theatre Journal aj. 


\section{Sémiotická analýza tance dnes: závěr}

České tanečněvědné uvažování, ostatně podobně jako i to teatrologické, se v mnoha aspektech při analýze představení dosud opírá zejména o možnosti využití sémiotické analýzy. Závěrem proto budiž krátce zmíněno, že také taneční věda, rekrutující se v německojazyčném akademickém prostředí z velké míry z postulátů a metod divadelní vědy, tento teoreticko-metodologický nástroj stále hojně a efektivně využívá, ovšem prostřednictvím určitých modifikací, kterými sémiotické nazírání tance v souladu s nejaktuálnějšími teoretickými koncepty prošlo.

Funkční podklad pro argumenty sémiotické analýzy, která se snaží vyložit pohyb jakožto znak (což může být u pohybů, které nelze číst jako konvencionalizovaná pantomimická komunikační gesta nebo která nejsou tvořena jako znak sám o sobě, komplikovanější), lze získat analýzou pohybu, jejímž cílem je pozorování, pojmenování a konceptualizace dané pohybové estetiky. V průběhu 20. století bylo vytvořeno několik variant k systematickému zaznamenání tanečního pohybu, mezi které patří pohybová analýza dle Labana a Bartenieff (Laban-Bartenieff Bewegungsanalyse), Kestenbergova metoda zápisu pohybu (Kestenberg Movement Profile), Movement Evaluation Graphics (MEG) a Inventarizace pohybu (Inventarisierung von Bewegung - IVB). ${ }^{21}$ Tyto metody zápisu či analýzy pohybu mají společné to, že tělo a prostor jakožto základní body k určení kvality pohybu, které tyto systémy zohledňují, jsou zde chápány jako dané abstraktní veličiny. Analýza čistého pohybu nepočítá s jakýmkoliv konceptuálním uchopením těla a prostoru, nicméně dokáže rozkrýt detaily pohybu určující účinek choreografie, co se týče atmosféry či energie. Nevýhodou těchto systémů v užití pro analýzu choreografie je fakt, že je velmi náročné zmapovat takto celou choreografii a recipient musí dobře znát zákonitosti daného systému, aby byl schopen myšlenkové směřování analýzy pojmout. Nicméně jakožto nástroj je analýza čistého pohybu užitečná zejména jako podklad pro kvalitní popis pohybové gramatiky choreografie, kterou lze získat z analýzy pouhé krátké sekvence, a tak i jako základ argumentace k interpretaci pohybu.

Sémiotická analýza tance si v jejím současném uplatnění neklade za cíl pojmout choreografii jakožto souhrn či ideologický plán, jímž se interpreti v jednotlivých představeních řídí a zároveň se jej snaží dosáhnout, ale choreografii pojímá spíše jako sít vztahů (tvořených charakterem pohybu, jednáním, prostorem, předměty na scéně), jež nabízí různé výklady a uchopení. ${ }^{22}$ Aplikace sémiotické analýzy na tanec totiž nechápe choreografii jako artefakt sám o sobě, ale jako performativ, který se mění nejen představení od představení, ale i na základě svého kontextu, který jej obklopuje. Lze říci, že tito badatelé mnohem více zohledňují procesualitu a mnohost výkladů choreografie. Důležitým aspektem sémiotické analýzy tance zajisté je, že pojímá choreografické dílo z odstupu a tolik ji nezajímá její tvůrčí fáze a hlas samotných tvůrco̊, jako je tomu často u analýz,

21 V antologii Methoden der Tanzwissensch aft. Modellanalysen zu Pina Bauschs, Le Sacre du Printemps/Das Frühlingsopfer' lze nalézt ukázky pohybové analýzy dle Labana a Bartenieff a inventarizace pohybu (IVB). Viz (HAITZINGER et al. 2015: 177-195; KENNEDY 2015).

22 V antologii Methoden der Tanzwissenschaft. Modellanalysen zu Pina Bauschs, Le Sacre du Printemps/Das Frühlingsopfer' viz např. (BOENISCH 2015: 35-52; THURNER 2015: 53-64). 
které si vypomáhají sociologickými či kulturálně-antropologickými koncepty. Vzájemnou provázaností a nazíráním tance z různorodých interdisciplinárních perspektiv, jež současné koncepty etablované v oblasti především humanitních věd nabízejí, lze však jednotlivé jeho projevy analyzovat a interpretovat jako specifické zpo̊soby myšlení. A ty se podílejí na kontextualizaci a konceptualizaci světa, který ted' a tady obdobně dynamicky a fluidně žijeme, (trans)formujeme a spoluurčujeme.

\section{Bibliografie}

AUSTIN, John Langshaw. 2000. Jak udělat něco slovy [How to Do Things with Words]. Překl. Alena Bakešová et al. Praha: Filosofia, 2000.

BAUER, Bojana. 2015. Propensity: Pragmatics and Functions of Dramaturgy in Contemporary Dance. In Pil Hansen and Darcey Callison (eds.). Dance Dramaturgy: Modes of Agency, Awareness and Engegement. London: Palgrave Macmillan, 2015: 31-50.

BLEEKER, Maaike. 2015. Thinking No-One's Thought. In Pil Hansen and Darcey Callison (eds.). Dance Dramaturgy: Modes of Agency, Awareness and Engagement. London: Palgrave Macmillan, 2015: 67-86.

BOENISCH, Peter M. 2015. Tanz als Körper-Zeichen: Zur Methodik der Theater-Tanz-Semiotik. In Gabriele Brandstetter und Gabriele Klein (Hrsg.). Methoden der Tanzwissenschaft. Modellanalysen zu Pina Bauschs ,Le Sacre du Printemps/Das Frühlingsopfer'. Bielefeld: transcript Verlag, 2015: 35-52.

BRANDSTETTER, Gabriele und Gabriele KLEIN (Hrsg.). 2015. Methoden der Tanzwissenschaft. Modellanalysen zu Pina Bauschs ,Le Sacre du Printemps/Das Frühlingsopfer'. Bielefeld: transcript Verlag, 2015.

BRANDSTETTER, Gabriele. 2007. Tanz als Wissenskultur. Körpergedächtnis und wissenstheoretische Herausforderung. In Sabine Gehm, Pirkko Husemann und Katharina von Wilcke (Hrsg.). Wissen in Bewegung. Perspektiven der künstlerischen und wissenschaftlichen Forschung im Tanz. Bielefeld: transcript Verlag, 2007: 37-49.

BUTLER, Judith. 2002. What is Critique? An Essay on Foucault's Virtue. In David Ingram (ed.). The Political: Readings in Continental Philosophy. London: Basil Blackwell, 2002: 212-226.

CVEJIĆ, Bojana. 2015. Choreographing Problems. New York: Palgrave Macmillan, 2015.

GEHM, Sabine, Pirkko HUSEMANN und Katharina VON WILCKE (Hrsg.). 2007. Wissen in Bewegung. Perspektiven der künstlerischen und wissenschaftlichen Forschung im Tanz. Bielefeld: transcript Verlag, 2007.

GOFFMAN, Erwing. 1971. Interaktionsrituale. Über Verhalten in direkter Kommunikation. Frankfurt am Main: Suhrkamp, 1971.

HAITZINGER Nicole, Claudia JESCHKE und Christiane KARL. 2015. Die Tänze der Opfer. Tänzerische Aktionen, Bewegungstexte und Metatexte. In Gabriele Brandstetter und Gabriele Klein (Hrsg.). Methoden der Tanzwissenschaft. Modellanalysen zu Pina Bauschs ,Le Sacre du Printemps/Das Frühlingsopfer‘. Bielefeld: transcript Verlag, 2015: 177-195.

HUSEMANN, Pirkko. 2009. Choreographie als kritische Praxis. Bielefeld: transcript Verlag, 2009.

IMBRASAITE, Jurgita. 2016. Das Begehren des Wissens im Tanz. In Milena Cairo, Moritz Hannemann, Ulrike Haß und Judith Schäfer (Hrsg.). Episteme des Theaters: Aktuelle Kontexte von Wissenschaft, Kunst und Öffentlichkeit. Bielefeld: transcript, 2016: 369-379. 
KENNEDY, Antja. 2015. Methoden der Bewegungsbeobachtung: Die Laban/Bartenieff Bewegungsstudien. In Gabriele Brandstetter und Gabriele Klein (Hrsg.). Methoden der Tanzwissenschaft. Modellanalysen zu Pina Bauschs, Le Sacre du Printemps/Das Frühlingsopfer‘. Bielefeld: transcript Verlag, 2015: 65-83.

KLEIN, Gabriele. 2007. Tanz in der Wissensgesellschaft. In Sabine Gehm, Pirkko Husemann und Katharina von Wilcke (Hrsg.). Wissen in Bewegung. Perspektiven der künstlerischen und wissenschaftlichen Forschung im Tanz. Bielefeld: transcript Verlag, 2007: 25-37.

KLEIN, Gabriele. 2013. Dance Theory as a Practice of Critique. In Gabriele Brandstetter and Gabriele Klein (eds.). Dance [and] Theory. Bielefeld: transcript Verlag, 2013: 137-153.

LEIGH FOSTER Susan. 2013. Dancing and Theorizing and Theorizing Dancing. In Gabriele Brandstetter and Gabriele Klein (eds.). Dance [and] Theory. Bielefeld: transcript Verlag, 2013: $19-35$.

LEPECKI, André. 2006. Exhausting Dance: Performance and the Politics of Movement. London: Routledge, 2006.

LYOTARD, Jean-François. 1984. The Postmodern Condition. A Report on Knowledge. Minneapolis: University of Minnesota Press, 1984.

NOETH, Sandra. 2011. Protocols of Encounter: On Dance Dramaturgy. In Gabriele Klein and Sandra Noeth (eds.). Emerging Bodies. The Performance of Worldmaking in Dance and Choreography. Bielefeld: transcript Verlag, 2011: 247-256.

PAVLIŠOVÁ, Jitka. 2018. „Tanec-koncept“, „ne-tanec“ nebo „nová choreografie“? Aktuální německojazyčný teoretický diskurs v oblasti taneční performance ['Dance-concept', 'Non-dance' or 'New Choreography'? Current German-language Theoretical Discourse in the Field of Dance Performance]. ArteActa 1 (2018): 5-23.

PLOEBST, Helmut. 2001. No wind no word: Neue Choroegraphic in der Gesellschaft des Spektakels. 9 Portraits. München: K. Kieser, 2001.

THURNER, Christina. 2015. Prekäre physische Zone: Reflexionen zur Aufführunsanalyse von Bauschs Le Sacre du Printemps. In Gabriele Brandstetter und Gabriele Klein (Hrsg.). Methoden der Tanzwissenschaft. Modellanalysen zu Pina Bauschs ,Le Sacre du Printemps/Das Frühlingsopfer‘ Bielefeld: transcript Verlag, 2015: 53-64.

VAN IMSCHOOT, Miriam. 2003. Anxious Dramaturgy. Women E Performance: A Journal of Feminist Theory 13 (2003): 2: 57-68.

VAN KERKHOVEN, Marianne. 1994. The Theatre is in the City and the City is in the World and its Walls are of Skin. State of the Union Speech [online]. Etcetera, 1994. [accessed on 07. 10. 2021]. Available online at: http://sarma.be/docs/3229.

VÖLCKERS, Hortensia. 2007. Vorwort. In Sabine Gehm, Pirkko Husemann und Katharina von Wilcke (Hrsg.). Wissen in Bewegung. Perspektiven der künstlerischen und wissenschaftlichen Forschung im Tanz. Bielefeld: transcript Verlag, 2007: 9-15.

WONG, Yutian and Jens Richard GIERSDORF. 2019. Introduction. In Jens Richard Giersdorf and Yutian Wong (eds.). The Routledge Dance Studies Reader. New York: Routledge, 2019: 1-15. 


\section{Mgr. Jitka Pavlišová, Ph.D.}

Univerzita Palackého v Olomouci, Filozofická fakulta

Katedra divadelních a filmových studií

Univerzitní 3, 77900 Olomouc, Česká republika

jitka.pavlisova@upol.cz

\section{Mgr. et Mgr. Barbora Liška}

Univerzita Palackého v Olomouci, Filozofická fakulta

Katedra divadelních a filmových studií

Univerzitní 3, 77900 Olomouc, Česká republika

barbora.liska01@upol.cz

Jitka Pavlišová je absolventkou oboru divadelní věda na Masarykově univerzitě v Brně a Universität Wien (zde se studiem germanistiky). V letech 2010-2013 absolvovala vědeckovýzkumné pobyty v rámci Ernst Mach- a Franz Werfel-Programm na Universität Wien a Rakouské akademii věd. Od roku 2013 působí na Katedře divadelních a filmových studií Univerzity Palackého v Olomouci jako odborná asistentka se zaměřením na výzkum tance a pohybové performance (taneční teorie, dispozitivy tance 20. století, transkulturální aspekty $\checkmark$ tanci) a na oblast současného divadla německojazyčného prostoru. Je kurátorkou tanečně- performativního programu mezinárodního festivalu Divadelní Flora Olomouc. V současnosti hostuje na frankfurtské Hochschule für Musik und Darstellende Kunst jako hlavní řešitelka vědeckovýzkumného tanečního projektu "Transkulturální identity těla v současném tanci a performanci", podpořeného stipendijním programem Alexander von Humboldt-Stiftung.

Jitka Pavlišová graduated in theatres studies at Masaryk University, Brno, and University of Vienna (German language and literature). Between 2010 and 2013, she had several research stays at the University of Vienna and the Austrian Academy of Sciences, with the support from the Ernst Mach and Franz Werfel Program. Since 2013, she has been working as an assistant professor at the Department of Theatre and Film Studies, Palacký University Olomouc, focusing on dance and physical theatre (dance theories, dispositifs of the $20^{\text {th }}$ century dance, transcultural aspects of dance) and contemporary German-speaking theatre. She is a curator of dance and performative program of the international theatre festival Divadelní Flora Olomouc. Currently, she guest-lectures at the Hochschule für Musik und Darstellende Kunst Frankfurt as the main researcher of the project 'Transcultural Identity of Body in Contemporary Dance and Performance', supported by the Alexander von Humboldt-Stiftung.

Barbora Liška (roz. Kašparová) absolvovala studium divadelní vědy a překladatelství němčiny na Masarykově univerzitě. Ve svém doktorském studiu, které nastoupila na Univerzitě Palackého v Olomouci, se věnuje výzkumu dramaturgie v performativním umění, jehož základem je tělo, pohyb a/nebo tanec (tzv. body-based artworks). Je spoluzakladatelkou a redaktorkou brněnského divadelního časopisu CEDIT - kontexty a přesahy Centra experimentálního divadla. Během studia absolvovala zahraniční pobyty na Ruhr Universität Bochum, Universität Wien a Justus Liebig Universität Gießen. 
Barbora Liška (née Kašparová) graduated in theatre and German language translation studies at the Masaryk University, Brno. In her PhD studies at the Palacký University in Olomouc, she focuses on the research of dramaturgy in the performative art, whose basis is body, movement and/or dance (so-called body-based artworks). She is a cofounder and editor of a Brnobased theatre magazine CEDIT - Contexts and Overlaps of the Center of Experimental Theatre. During her studies, she participated in study stays at the Ruhr-University Bochum, University of Vienna and Justus Liebig University Gießen. 